\title{
DNA damage and repair process in earthworm after in-vivo and in vitro exposure to soils irrigated by wastewaters
}

\author{
Min Qiao, Ying Chen, Chun-Xia Wang, Zijian Wang*, Yong-Guan Zhu \\ State Key Laboratory of Environmental Aquatic Chemistry, Research Center for Eco-Environmental Sciences, \\ Chinese Academy of Sciences, Beijing 100085, China
}

Received 22 August 2006; received in revised form 19 October 2006; accepted 22 October 2006

\begin{abstract}
A non-linear dose-response relationship exists between earthworm DNA damage, measured with comet assay, and total PAHs levels in soils irrigated by wastewaters.
\end{abstract}

\begin{abstract}
In this study, DNA damage to earthworms (Eisenia fetida) after in vivo exposure to contaminated soils was measured by detecting DNA strand breakages (DSBs) and causality was analyzed through fractionation based bioassays. A non-linear dose-response relationship existed between DNA damage and total soil PAHs levels. DNA damage, measured with the comet assay, and its repair process, were observed. To identify the chemical causality, an in vitro comet assay using coelomocytes was subsequently performed on the fractionated organic extracts from soils. The results showed that the PAHs in the soils were responsible for the exerting genotoxic effects on earthworms. When normalized to benzo(a)pyrene toxic equivalent $\left(\mathrm{TEQ}_{\mathrm{BaP}}\right)$, the saturation dose in the dose-response curve was about $10 \mathrm{ng} \mathrm{TEQ}_{\mathrm{BaP}} \mathrm{g}^{-1}$ soil ( $\mathrm{dw}$ ).
\end{abstract}

(C) 2006 Elsevier Ltd. All rights reserved.

Keywords: Genotoxicity; Earthworm; Contaminated soil; PAHs; Comet assay

\section{Introduction}

Many genotoxic pollutants have been introduced into soils through anthropogenic pathways such as improper disposal of industrial wastes, wastewater irrigation (Chen et al., 2004), pesticide application and accidental leakage/spillage occurring during transport and storage of industrial materials. Particularly, mutagenic aromatic hydrocarbons and their derivatives (e.g., PAHs, nitroarenes, quinolines, thiophenes, etc.) from industrial and domestic combustion of fossil fuels and biomass contribute considerably to the pollution. These compounds can not only induce carcinogenesis, teratogenesis, and embryotoxicity in animals, but may also adversely affect ecosystem health (Mitchelmore and Chipman, 1998). With increasing

\footnotetext{
* Corresponding author. Tel./fax: +86 1062849140.

E-mail address: wangzj@rcees.ac.cn (Z. Wang).
}

in industrial production and organic wastes release, more attention needs to be focused on the ecological risks of genotoxic organic pollutants in terms of their chronic long-term presence in the soil environment (White and Claxton, 2004).

Assessment of the genotoxicity of compounds in terrestrial ecosystems presents a number of challenges, due to the diverse and complex nature of these environments. In vivo bioassays provide a more reliable assessment of toxicity because they are able to better preserve the natural soil conditions, allowing integration of a broad range of factors that contribute to the overall toxic effects (Alexander, 2000; Donnelly et al., 2004). For contaminants whose principle effects are on the genetic functioning of organisms, quantification of the genetic damage in terms of the number of DNA strand breaks (DSBs) is a promising approach. The comet assay is capable of examining DSBs in individual eukaryotic cells after in vivo or in vitro exposure and is considered to be a sensitive biomarker for identification and quantification of genotoxicity 
(Faust et al., 2004). The consequences of exposure and metabolism of carcinogens can be assessed by DNA damage as revealed by the level of DNA bulky adducts or by the number of DSBs (Farmer et al., 2003; Husgafvel-Pursiainen, 2004). Also, DSBs may result from the incomplete excision repair of DNA adducts, cross-links and alkali-labile sites when high alkaline conditions occur (Pfuhler and Wolf, 1996; De Boeck et al., 2000).

Usually, Eisenia fetida is used as a standard earthworm species for in vivo and in vitro bioassays (OECD, 1984; ISO, 1993). There have been few studies on the assessment of genotoxic risks of contaminated field soils for earthworms due to the difficulties in quantifying exposure levels, bioavailability, and effects (White and Claxton, 2004). Even fewer bioassay-directing analyses have focused on the chronic mutagenicity/genotoxicity of pollutants to terrestrial animals. Therefore, The objective of this study was to determine time-dependent DNA damage and its repair process in earthworms exposure to contaminated field soils with persistent organic pollutants. Combination of in vivo and in vitro bioassay as well as chemical analysis were conducted to better understand the genotoxic effects of contaminated soils and assess their risk to terrestrial invertebrates.

\section{Materials and methods}

\subsection{Chemicals}

Low melting point (LMP) agrose, normal melting point (NMP) agrose, triton X-100, DMSO, Tris, guaiacol glyceryl ether, ethidium bromide (EB) and $\mathrm{Na}_{2} \mathrm{EDTA}$ were purchased from Sigma Co. (Germany). Alumina (50200 mesh), silica gel (60-200 mesh), the 16 mixed PAHs standard (Cat. No. 48905-U) and the 17 mixed OCPs standard (Cat No. 47913) were purchased from Supelco Co, USA.

\subsection{Sampling, extraction and separation}

Soil samples were collected from a representative farmland receiving wastewater irrigation on the outskirts of Beijing, China (Fig. 1). This area had been irrigated for a long period with water pumped from rivers that had received sewage and effluents from industrial plants for many years. In the recent few years reclaimed water was used for irrigation instead. A relatively cleaner farmland, RS, was designated as the reference soil, which had always been irrigated by ground water. Contaminated soils were collected in effluent irrigated farmlands at U1, U2, D1 and D2 along the irrigation channel; U1 and U2 were irrigated by branches from upstream of the effluent, while, D1 and D2 by branches downstream (Fig. 1). For every plot, 5-6 cores of surface soils (to a depth of $20 \mathrm{~cm}$ ) were randomly collected and mixed thoroughly, representing one sample. Main properties of the soil were measured with $\mathrm{pH} 7.2$ (soil: water, $1: 5$ ), sand $24 \%$, silt $42 \%$ and clay $36 \%$. After sieving ( $2 \mathrm{~mm}$ mesh) and homogenizing, soils were freeze-dried and stored at $-20{ }^{\circ} \mathrm{C}$ until use.

Twenty grams of freeze-dried soil were Soxhlet extracted for $72 \mathrm{~h}$ with $200 \mathrm{ml}$ dichloromethane. Small copper sheets were added to remove sulfur. The extracts were concentrated by a rotary evaporator (BÜCHI R-200, Switzerland) at $39^{\circ} \mathrm{C}$ under vacuum of $500 \mathrm{mbar}$ to ca. $5 \mathrm{ml}$ (Chen et al., 2005). The volume was further reduced to ca. $1 \mathrm{ml}$ under a gentle stream of nitrogen (Ultra purity, Tangan, China). The extract was then cleaned up over an alumina/silica adsorption chromatography capped with anhydrous sodium sulfate to remove water. The first fraction (F1) containing alkyl hydrocarbon was eluted with $15 \mathrm{ml}$ of hexane. The second fraction (F2) including PAHs and OCPs was collected by eluting with $70 \mathrm{ml}$ of a dichloromethane and hexane mixture (3:7). The third fraction (F3) including phenols was collected by

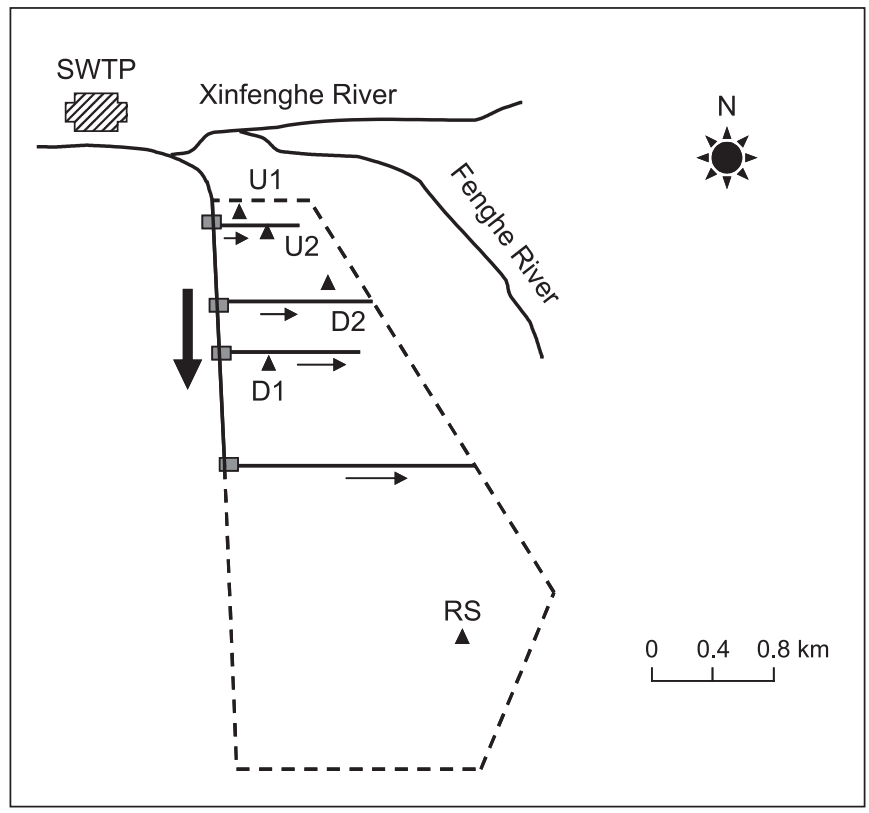

Fig. 1. Sampling location and irrigation scheme. (SWTP, the sewage treatment plant. The Xinfenghe River, receiving sewage and industrial effluents. RS, where relatively clean soils irrigated by ground water were collected and designated as the reference soil. U1, U2, D1 and D2, where contaminated soils collected along the irrigation channel; U1, U2 irrigated by branches from upstream of the mixed effluent and D1, D2 irrigated by branches from downstream.)

eluting with $30 \mathrm{ml}$ dichloromethane: methanol mixing (9:1). The volume of each organic fraction was reduced to ca. $1 \mathrm{ml}$ before $10 \mathrm{ml}$ of hexane was added. The fractions were then evaporated again under a stream of nitrogen to $1 \mathrm{ml}$ before being used for the in vitro bioassay and instrumental analysis of PAHs.

\subsection{Animal treatment and genetic diagnosis}

Earthworms (Eisenia fetida) were maintained in dark in a 1:1 mixture of clean soil (taken from a forest far from cities) and cattle manure at $23 \pm 2{ }^{\circ} \mathrm{C}$. The moisture content was adjusted to $35 \%$ of the final weight with dechlorinated water. Earthworms chosen in the assay were about $350 \mathrm{mg}$ with well-developed clitellum. All exposures were conducted at $23 \pm 2{ }^{\circ} \mathrm{C}$ under continuous light to ensure that the earthworms remained in the soil.

For the in vivo bioassay, selected worms about $350 \mathrm{mg}$ in weight with obvious adult clitellum were starved for $48 \mathrm{~h}$ on filter paper soaked with phosphate-buffered saline (PBS) buffer before exposure. Earthworms were then divided into four groups and assigned to exposure times of 1, 3, 7 and $14 \mathrm{~d}$. In each group, $100 \mathrm{~g}$ freeze-dried soil samples were blended with distilled water in a glass vessel, then 3 healthy worms were laid in it under lamplight to prevent them escaping from the soils. During exposure tests, dechlorinated water was sprayed into vessels every day to replenish the water loss. As an experimental quality control and to test for effects of soil texture, the 1:1 mixture of clean forest soil and cattle manure, was used as blank control (BK) soil in the lab, while the RS soil (as mentioned above, never receiving wastewater and locating around the contaminated field) was designated as a reference soil for the field samples. Prior to cell collection, earthworms were rinsed in icecold $0.85 \% \mathrm{w} / \mathrm{v} \mathrm{NaCl}$ solution and fecal matter was expelled. Then, individual earthworms were put into eppendorf tubes containing extrusion medium (EM) and their coelomocytes were obtained according to the non-invasive extrusion method (Eyambe et al., 1991; Zang et al., 2000). The extrusion medium was consisted of $5 \%$ ethanol, $95 \%$ saline, $2.5 \mathrm{mg} \mathrm{ml}^{-1}$ EDTA, and $10 \mathrm{mg} \mathrm{ml}^{-1}$ guaiacol glyceryl ether $(\mathrm{pH}=7.3)$. Coelomocytes were spontaneously 
secreted in the medium and washed with PBS buffer prior to the comet assay. The cells were collected by centrifugation and put on ice before the comet assay. For in vitro bioassay, cell cultures (with a final cell density $5-6 \times 10^{-5}$ ) were incubated in darkness for $18 \mathrm{~h}$ in Hanks buffer mixed with DMSO-dissolved organic extracts (ratio 1:1) with a final concentration of DMSO of $0.1 \%$ in the culture solution. An aliquot of $0.30 \mathrm{ng} \mathrm{ml}^{-1}$ individual 16-PAHs (DMSO-dissolved and mixed with the cell culture as for the soil extracts) and $10 \mathrm{ng} \mathrm{ml}^{-1}$ Mitomycin C (MMC), a potent mutagen, were also exposed to the cells as positive controls (PK). After exposure, cell cultures were centrifuged for 6-8 min at $150 \mathrm{~g}$ at $4{ }^{\circ} \mathrm{C}$, then washed and re-suspended in PBS buffer. Cell viability was checked before the comet assay using typan blue dye method. DNA damage was analyzed only when viability of cell cultures reached $85 \%$. A solvent control (SK) was included, which consisted of organic solvents with the same ratio and amounts as used in the soil extraction and separation procedure, for the consideration of the possible effects on the cells of the chemical solvents.

The comet assay was performed as described by Singh et al. (1988) with slight modification. All steps were conducted under dim red light and performed at $4{ }^{\circ} \mathrm{C}$ to prevent additional DNA damage. An aliquot of $10 \mu \mathrm{l}$ cell suspension was carefully mixed with $75 \mu 10.75 \%$ (w/v in PBS) LMP agrose at $37^{\circ} \mathrm{C}$, and placed on a microscopic slide pre-coated with $100 \mu \mathrm{l}$ NMP agrose $(1 \% \mathrm{w} / \mathrm{v}$ in PBS). The gel was solidified on ice for $15 \mathrm{~min}$, the cover slip removed, and the slides transferred to the lysis buffer for $1 \mathrm{~h}\left(4{ }^{\circ} \mathrm{C}\right.$, $2.5 \mathrm{M} \mathrm{NaCl}, 100 \mathrm{mM} \mathrm{Na}{ }_{2}$ EDTA, $10 \mathrm{mM}$ Tris, supplemented with $1 \%$ Triton $\mathrm{X}-100$ and 10\% DMSO just before use). After gentle washing in ice cold distilled and deionised water, two slides of each sample were placed side-by-side in a horizontal electrophoresis tank filled with a $4{ }^{\circ} \mathrm{C}$ buffer containing $300 \mathrm{mM} \mathrm{NaOH}, 1 \mathrm{mM} \mathrm{Na} \mathrm{F}_{2} \mathrm{EDTA}(\mathrm{pH}>13$ ) for $20 \mathrm{~min}$ to make the DNA unwind. Alkaline electrophoresis was performed in the same buffer for $20 \mathrm{~min}$ at $25 \mathrm{~V}, 300 \mathrm{~mA}$. After washing three times for $5 \mathrm{~min}$ each with neutralization buffer (0.4 M Tris, $\mathrm{pH} 7.5)$, the slides were dehydrated in ice-cold ethanol $(10 \mathrm{~min})$ and taken out to dry. Prior to the analysis of comets, $80 \mu \mathrm{l}$ $20 \mathrm{~g} \mathrm{ml}^{-1} \mathrm{~EB}$ were added to each agrose spot and the stained slides were kept in a humidified dark-box. The slides were analyzed with a fluorescence microscope (Axioskop 2 mot plus, Zeis, Germany) equipped with a CCD camera (Axio CAM MRM, Zeis, Germany) and an excitation filter of BP $520 \mathrm{~nm}$ and a barrier filter LP $610 \mathrm{~nm}$. For each parallel set of slides, 50 non-overlapping comets were captured randomly at $400 \times$ magnification and a total of 100 cells were scored for each sample. The captured images were measured using an image analysis system (Axiovision 4.1) and three parameters were recorded and calculated including tail length (TL) (the distance from nuclear center to the end of the comet tail), tail DNA (TD) percentage (expressed by the percent of fluorescent intensity in tail) and tail moment (the product of TL and TD). Tail moment (TM) was measured by the computerized image analysis system and encompasses both the length of DNA migration in the comet tail and the tail intensity. TM is considered to be one of the best indices of induced DNA damage among the various parameters (De Boeck et al., 2000).

\subsection{Chemical analysis}

PAHs in soil samples were identified and quantified by a Hewlett Packard 6890 gas chromatography (HP-5 capillary column, $60 \mathrm{~m} \times 0.25 \mathrm{~mm}$ ID, and $0.25 \mu \mathrm{m}$ film thickness) equipped with a 5973 mass spectrometer detector (Agilent Co. USA). Oven temperature was programmed from $50{ }^{\circ} \mathrm{C}$ (initial time, $2 \mathrm{~min}$ ) to $200{ }^{\circ} \mathrm{C}$ at a rate of $20{ }^{\circ} \mathrm{C} \mathrm{min}-1$, then from $200{ }^{\circ} \mathrm{C}$ to $240^{\circ} \mathrm{C}$ at a rate of $5^{\circ} \mathrm{C} \mathrm{min}^{-1}$ with a hold for $2 \mathrm{~min}$, and finally increased to $300{ }^{\circ} \mathrm{C}$ and held for $15 \mathrm{~min}$. Injections $(1 \mu \mathrm{l})$ were made in the splitless mode, and helium at a constant flow rate of $1 \mathrm{ml} \mathrm{min}^{-1}$ was used as the carrier gas. The PAH mixed standard including 16 priority PAHs was identified using Method-8310 (the U.S. Environmental Protection Agency). Selected ion monitoring (SIM) mode was carried out using the molecular ions selective for individual PAHs. Chromatographic data was collected and processed using HP Chemstation software. Quantification for individual PAHs was performed using the internal standard and five-point calibration curve.

OCPs were quantified by a gas chromatography equipped with a ${ }^{63} \mathrm{Ni}$ Electron capture detector using (Hp-5 capillary column, $30 \mathrm{~m} \times 0.32 \mathrm{~mm} \mathrm{ID}$, and $0.25 \mu \mathrm{m}$ film thickness). The oven temperature was programmed from $85{ }^{\circ} \mathrm{C}$ (initial time, $2 \mathrm{~min}$ ) to $180{ }^{\circ} \mathrm{C}$ at a rate of $10^{\circ} \mathrm{C} \mathrm{min}^{-1}$, and held at $180{ }^{\circ} \mathrm{C}$ for $15 \mathrm{~min}$, then programmed to $280^{\circ} \mathrm{C}$ at a rate of $20^{\circ} \mathrm{C} \mathrm{min}{ }^{-1}$ with a final hold of $3.5 \mathrm{~min}$. Injections $(1 \mu \mathrm{l})$ were made in the splitless mode and nitrogen at flow rate of $3.4 \mathrm{ml} \mathrm{min}^{-1}$ was used as the carrier gas. Injector and detector temperatures were $280{ }^{\circ} \mathrm{C}$ and $300^{\circ} \mathrm{C}$, respectively. Individual OCPs were quantified from five-point calibration curves.

Recoveries of compounds were examined by spiking $50 \mathrm{ng} \mathrm{g}^{-1} \mathrm{dw}$ PAHs mixture standard and $50 \mathrm{ng} \mathrm{g}^{-1} \mathrm{dw}$ OCPs mixture standard in four repeated less-contaminated soils purified by acetone ( $48 \mathrm{~h}$, Soxhlet extraction). The recoveries for all individual OCPs investigated were in the range $80-103 \%$ and for PAH, the values were from 59\% to $114 \%$ (except for the lowest recovery of naphthalene of $59 \%$, that of the other individual PAHs was more than $80 \%$ ). In this study, the final concentrations of compounds in soils were reported on a dry weight basis and not corrected for recovery efficiencies. The detection limits were in range of $0.15-0.75 \mathrm{ng} \mathrm{g}^{-1} \mathrm{dw}$ for OCPs and 0.47$2.5 \mathrm{ng} \mathrm{g}^{-1} \mathrm{dw}$ for PAHs, respectively.

\subsection{Statistical analysis}

All analyses were carried out using the SPSS 11.5 statistical package. Comet data were found to be abnormally distributed and therefore non-parametric statistical methods were employed. Significant differences $(P<0.05)$ between treatment groups were determined with Mann-Whitney $U$-(Twotailed) test and the Kruskal-Wallis test $(\alpha$ level, $P<0.05)$. Boxplot was used to describe distribution of TM values, which allows the evaluation of possible outliers, such as apoptotic cells. The data distributed in the middle $50 \%$ range of the values were located in the box while other values ranked in the highest $25 \%$ and the lowest $25 \%$ were excluded from the box.

The PEF (potency equivalency factor) approach to calculate the carcinogenicity of PAHs was applied in this study, by multiplying the single PAH concentration and its BaP toxicity equivalent factors (TEF) before summing the single BaP toxicity equivalents. The values of every single TEF in other studies were used in calculating the results (Nisbet and LaGoy, 1992; Larsen and Larsen, 1998). In simulating relationship of DNA damage and PAH concentrations in soils, TM values were $\log _{10}$-transformed. Normality and the homogeneity of variance were verified by the Kolmogorov-Smirnov test and the Barlett test, respectively. Sigmoid non-linear curve-fitting was performed with Origin 7.0.

\section{Results}

\subsection{Genotoxicity after in vivo exposure}

TM, the product of comet tail length and tail intensity, was chosen to express the final comet assay results. TM distribution of comets in each sample group was described in a boxplot and the mean TM value was calculated and marked within each box to quantify the DNA damage. As shown in Fig. 2, significantly higher DNA damage occurred in earthworms exposed to soils under wastewater irrigation (U1, U2, D1 and D2) than those exposed to blank control and reference soils. The TM values of DNA damage in the BK and RS groups remained low and consistent throughout the 1, 3, 7, $14 \mathrm{~d}$ exposure periods. A time-dependent response of DSBs in earthworms was found, with DNA damage increasing initially but recovering towards the end of each exposure time. Greater DSBs with mean TM ranging from $25 \mu \mathrm{m}$ to $45 \mu \mathrm{m}$ were shown for $3 \mathrm{~d}$ and $7 \mathrm{~d}$ exposures. At $14 \mathrm{~d}$ endpoint, DSBs caused by U1 and U2 soils were still greater than those of BK and RS groups while DSBs caused by other soils reached the background levels, equal to the values in BK and RS groups. 

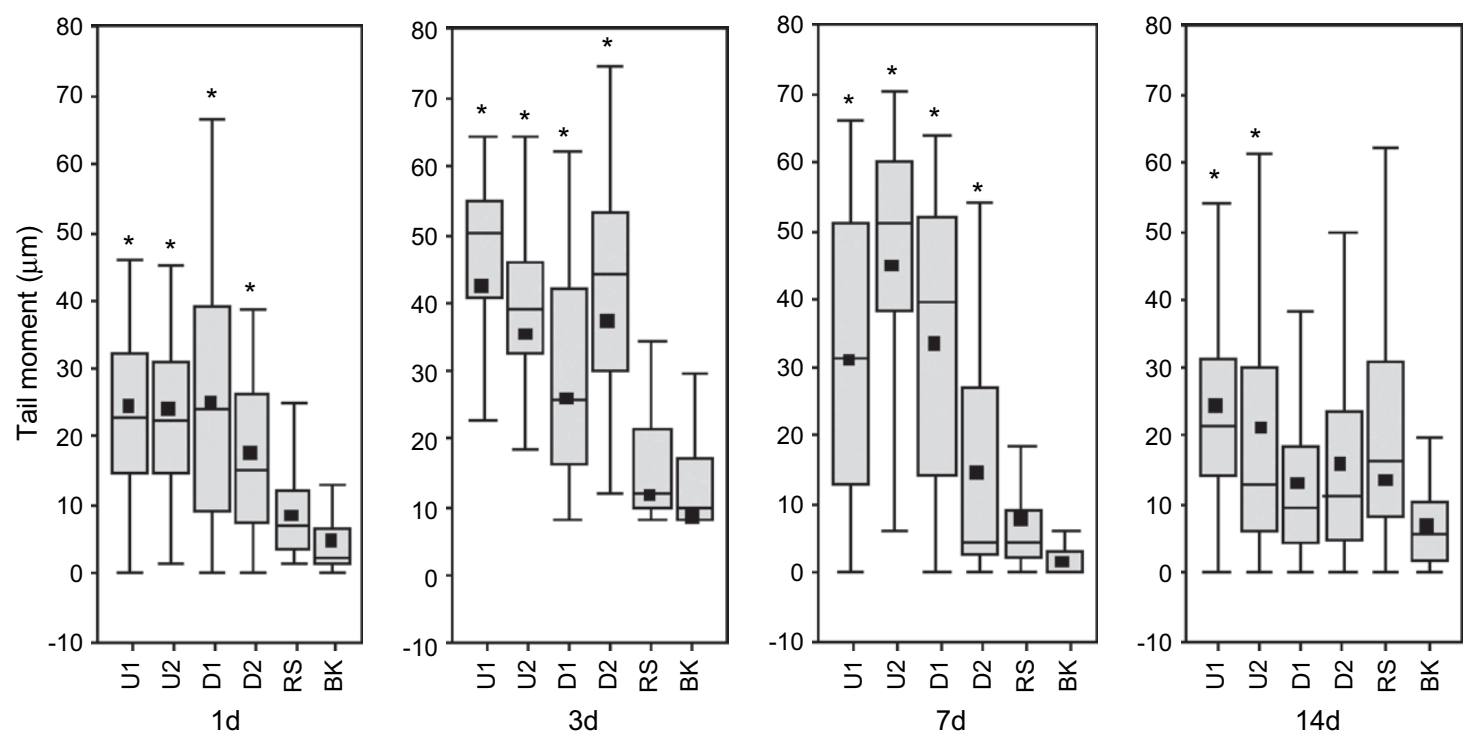

Fig. 2. Distribution and mean levels of DSBs in coelomocytes of earthworm (Eisenia fetida) exposed to soils for 1-14 d in vivo bioassay (BK, blank control; mean value of tail moment; $*: p<0.05$, as compared to the reference soil).

\subsection{PAHs concentrations in soils}

Concentrations of PAHs ranged from 228.4 to $67.2 \mathrm{ng} \mathrm{g}^{-1} \mathrm{dw}$ in soils with wastewater irrigation (U1, U2, $\mathrm{D} 1, \mathrm{D} 2$ ) and $30.7 \mathrm{ng} \mathrm{g}^{-1} \mathrm{dw}$ in the RS soil (Table 1). Relatively higher concentrations of the total PAHs were found in upriver soils with $\mathrm{U} 1,181.6 \mathrm{ng} \mathrm{g}^{-1}$, and $\mathrm{U} 2,228.4 \mathrm{ng} \mathrm{g}^{-1}$ than downriver soils with D1, $82.8 \mathrm{ng} \mathrm{g}^{-1}$, and D2, $67.2 \mathrm{ng} \mathrm{g}^{-1}$, respectively. However the OCPs, another group of persistent organic pollutants, were found to be present at lower concentrations in the farmland soils (Table 1). Total OCPs in soils ranged from below detection limits to $15.80 \mathrm{ng} \mathrm{g}^{-1}$ and no detectable OCPs were found in soils of U1 and RS. Among the OCPs detected, HCHs and DDTs had the most frequent occurrence.

\subsection{Correlations between DSBs and PAHs in soil}

A non-linear dose-response relationship was found between DSBs and PAH concentrations in the soils; DSBs plotted against PAH concentrations increased fast from background and arrived at a saturation level after 3 days of exposure (Fig. 3). Two PAH expressions were used to analyze the results, total PAHs and the $\mathrm{BaP}$ toxicity equivalents $\left(\mathrm{TEQ}_{\mathrm{BaP}}\right)$ since benzo(a)pyrene is the only PAH for which EPA has derived a cancer slope factor and for which toxicological data are sufficient for derivation of potency equivalency factor among all known potentially carcinogenic PAHs (Peters et al., 1999). Employing the PEF approach, genotoxicity of 16PAHs group can be effectively summed and expressed as equivalents to $\mathrm{BaP}$ toxicity, it is therefore useful to compare possible genotoxicity of PAHs from different soils. DSBs versus total PAHs and $\mathrm{TEQ}_{\mathrm{BaP}}$ in soils fitted sigmoid curves well for different exposure times and the relationship was
Table 1

Concentrations of individual PAH and OCP compounds, total PAHs, total $\mathrm{TEQs}_{\mathrm{BaP}}$ and total organic carbon (TOC) in soils irrigated by wastewaters on the outskirts of Beijing, China

\begin{tabular}{|c|c|c|c|c|c|}
\hline \multirow[t]{2}{*}{ Substance } & \multicolumn{5}{|c|}{ Concentrations in soils } \\
\hline & $\mathrm{U} 1$ & $\mathrm{U} 2$ & D1 & $\mathrm{D} 2$ & RS \\
\hline TOC & $1.93 \%$ & $2.22 \%$ & $1.91 \%$ & $1.36 \%$ & 2.49 \\
\hline \multicolumn{6}{|c|}{ PAH concentrations in soils $\left(n g g^{-1} d w\right)$} \\
\hline $\operatorname{Nap}(0.001)^{\mathrm{a}}$ & 28.1 & 28.3 & 15.8 & 11 & 4.8 \\
\hline Acy $(0.001)$ & 1.4 & 1.7 & 0.6 & 0.4 & 0.3 \\
\hline Ace $(0.001)$ & 0.9 & 1.0 & 0.4 & 0.3 & ND \\
\hline Flu (0.001) & 5.6 & 6.1 & 2.4 & 1.5 & 0.7 \\
\hline Phe $(0.0005)$ & 23.9 & 24.5 & 9.7 & 7.9 & 2.6 \\
\hline Ant $(0.0005)$ & 1.4 & 1.9 & 0.7 & 0.5 & 0.2 \\
\hline Fla $(0.05)$ & 17.9 & 23.4 & 7.6 & 6.2 & 2.1 \\
\hline Pyr (0.001) & 15.1 & 22.5 & 7.3 & 6.0 & 2.1 \\
\hline Chr (0.03) & 8.6 & 11.4 & 4.2 & 3.4 & 1.5 \\
\hline $\mathrm{BaA}(0.005)$ & 9.5 & 12.7 & 3.2 & 3.8 & 1.2 \\
\hline $\mathrm{BkF}(0.05)$ & 5.9 & 8.1 & 2.8 & 2.4 & 1.6 \\
\hline $\mathrm{BbF}(0.1)$ & 20.5 & 27.3 & 9.6 & 8.2 & 3.2 \\
\hline $\mathrm{BaP}(1)$ & 10.5 & 15.4 & 4.8 & 4.0 & 2.2 \\
\hline $\operatorname{IcdP}(0.1)$ & 13.2 & 18.5 & 6.2 & 5.1 & 3.9 \\
\hline DahA (1.1) & 3.9 & 4.9 & 1.4 & 1.5 & 2.6 \\
\hline BghiP (0.02) & 15.4 & 20.7 & 6.1 & 5.0 & 1.7 \\
\hline Total PAHs & 181.8 & 228.4 & 82.8 & 67.2 & 30.7 \\
\hline Total TEQ $\mathrm{BaP}$ & 27.8 & 19.9 & 8.7 & 7.6 & 13.1 \\
\hline \multicolumn{6}{|c|}{ OCP concentrations in soils $\left(n g g^{-1} d w\right)$} \\
\hline $\mathrm{HCHs}$ & ND & 0.70 & 0.84 & 5.58 & ND \\
\hline Aldrin & ND & 0.43 & 0.27 & 0.59 & ND \\
\hline Chlordane & ND & 0.43 & ND & 0.44 & ND \\
\hline DDTs & ND & 3.18 & 0.32 & 9.20 & ND \\
\hline Endsulfen I & ND & 3.87 & ND & ND & ND \\
\hline Total OCPs & ND & 7.79 & 0.80 & 15.80 & ND \\
\hline
\end{tabular}

${ }^{a}$ The value in brackets refers to the toxicity equivalent factor of each PAH and was cited from Nisbet and LaGoy (1992) and Larsen and Larsen (1998). 



Fig. 3. Time-dependent dose-response relationships between PAH level and earthworm (Eisenia fetida) DNA damage in soil. The dose was expressed as the total concentration of PAHs (above) and BaP toxicity equivalents, $\mathrm{TEQ}_{\mathrm{BaP}}$ (below). closer before DNA repair processes were initiated. Good correlations were acquired $(P<0.05)$ between DNA damage and $\mathrm{PAH}$ concentrations when performing sigmoid non-linear curve-fitting. The correlation coefficients $\left(R^{2}\right)$ of DSBs and total PAHs were in the range of $0.707-0.999$ and those of DSBs and TEQ $\mathrm{BaP}$ ranged from 0.677 to 0.999 .

\subsection{Genotoxicity after in vitro exposure}

As seen from Fig. 4, DSBs were induced significantly in organic fractions F1 (containing alkyl hydrocarbons) and F2 (containing PAHs and OCPs), especially for U1, U2, and D1. Furthermore, DSBs in F2 fraction exhibited more obvious DNA damage. However, there was no significant difference for DSBs in the F3 fraction for any of the contaminated samples. Very few DNA-damaged cells were found in fractions of the blank control and RS soil in contrast to obvious DSBs in the positive control, $10 \mathrm{ng} \mathrm{ml}^{-1} \mathrm{MMC}$ and $4.8 \mathrm{ng} \mathrm{m}^{-1}$ PAHs standard mixture.

\section{Discussion}

Two main mechanisms are known to cause DSBs including exogenous agents and endogenous species. DNA may be damaged directly by chemicals (like $\mathrm{H}_{2} \mathrm{O}_{2}$ ) or indirectly by by-products of organic xenobiotics (like PAHs), metabolites, transition metals, or from oxidised free radicals in endogenous metabolism (Mitchelmore and Chipman, 1998; Faust et al., 2004).

The significant DNA damage in earthworms exposed to contaminated soils can be attributed to the pollutants released from the sewage and industrial effluents and absorbed to the soils. Genotoxic pollutants, such as PAHs, pesticides and heavy metals, are well known to easily adsorb onto particulate matter and accumulate in soils. From the results, it appeared


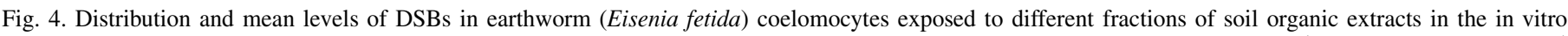

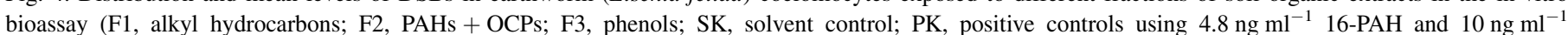
MMC, respectively; $\mathbf{\square}$ : mean value of tail moment; $*: p<0.05$, as compared to the reference soil. 
that the main contributors to genotoxicity of earthworms were the PAHs in the contaminated soils.

As put forward in other studies, the comet parameters tended to be heterogeneous and the peaks of the distributions shifted upward with increasing doses of the genotoxicant (Pandrangi et al., 1995). Similarly in our study, using either in vivo or in vitro bioassays, both non-damaged DNA and seriously fragmented DNA were found in almost all the groups and the distribution was not homogenous, even though the dominant ratio of DSBs shifted to the serious or less damaged population depending on the exposure time. The constant low DSBs levels in the controls are assumed to be the background values derived from endogenous and unavoidable exogenous sources (Lutz, 1998). However, DSBs of the pollutant exposure groups showed significantly higher levels compared with the controls, which points to exogenous genotoxic pollutants as a major cause of the genetic damage. The question then arises, which are the most damaging compounds?

The non-linear dose-response relationship between DSBs and PAH concentrations of soils during the in vivo exposure might partly answer this question. It was verified by the in vitro assay that DSBs were induced predominately in the organic fraction containing PAHs which produce genotoxic effects by enzyme activation in vertebrates (Nesnow et al., 1998; Sayles et al., 1999; Roos et al., 2004; Saint-Denis et al., 1999).

The time-dependent DSBs variations were considered to mainly result from a dynamic balance between DNA damage and repair activities. According to our results, earthworms exposed to the contaminated soils were slower to repair DNA and still showed significant DNA-damaged at the end of the 14 day exposure period. In contrast, earthworms exposed to the relatively cleaner soils recovered faster. Non-polar molecules such as PAHs need to be metabolized before showing chronic genotoxicity (Livingstone, 1991). Ching et al. (2001) suggested that some DNA repair systems may be activated after the invertebrate tissue has accumulated sufficient toxicant above a threshold level. Below this level, the DNA repair activity may be facilitated only by a basal level of DNA repair enzymes so that the damaged DNA is easier to be repaired. In this study, DSBs in earthworms continued increasing after at least $1 \mathrm{~d}$ and continued for at least $14 \mathrm{~d}$ of exposure, indicating a chronic DNA-damage process. Nevertheless, the aging history of pollutants in soils might also influence their availabilities for earthworms and thus contribute to the changes in DNA damage degree (Alexander, 2000; Lanno et al., 2004).

Based on these results, it is suggested that the non-linear curve (Fig. 3) of DNA damage vs PAH concentration can be used to calculate the risk to invertebrates of PAH soil pollution, similar to toxicity potency assessment of carcinogenic adducts for mammals previously discussed (Larsen and Larsen, 1998; Lutz, 1998). That is, at low carcinogen doses, DNA damage responded linearly but with doses increasing, a sublinear deviation follows for detoxification reactions, or DNA repair processes are saturated. The slope and the saturation level were considered as candidates for estimating the carcinogen potency. Hence, the genotoxicity risk of low-level PAHs on earthworms is higher when DNA damage increases faster over background and the saturation level of PAHs in the non-linear part can reflect the tolerance of earthworms to PAH pollution. The slope of the linear part and the concentration of PAHs when DSBs repair occurs and the damage reaches a saturation level can be useful to assess the DNA damage potency to earthworms, although the mechanisms of PAH metabolism in earthworms are not yet clear. As seen in Fig. 3, the highest slope was found when DSBs reached a near-saturation level after 3 days of exposure. The saturation dose before DNA repair occurred was about $10 \mathrm{ng} \mathrm{g}^{-1} \mathrm{dw}$ $\mathrm{TEQ}_{\mathrm{BaP}}$, which can be used as the benchmark for genotoxicity to earthworms of PAHs-like chemicals in soils. Above this level, the detoxification abilities of earthworms appear to be limited. Although no ecologically relevant parameters such as survival, growth and reproduction which are endpoints for ecological risk assessment were included, this case study provides mechanisms or mode of action that is fundamental to improve the scientific basis of risk assessment (Escher and Hermens, 2002).

\section{Conclusion}

A dynamic DSBs and repair process was found when earthworms were exposed to soils irrigated by wastewater. Fractionation-based in vitro bioassay on coelomocytes of earthworms suggested PAHs to be responsible for the genotoxicity. It was suggested that the slope of the dose-response relationship between DSBs in earthworm coelomocytes and $\mathrm{PAH}$ levels, and the saturation $\mathrm{PAH}$ dose before the initiation of DNA repair could be useful parameters to measure the genotoxicity potency of PAH-like compounds to earthworms. The saturation dose before DNA repair occurred was about $10 \mathrm{ng} \mathrm{g}^{-1} \mathrm{dw} \mathrm{TEQ}_{\mathrm{BaP}}$, which can be used as the benchmark.

\section{Acknowledgement}

We sincerely thank Professor Robert Reid, The University of Adelaide, for critical reading of the manuscript and making a number of helpful suggestions. This work was supported by National Basic Research Program of China (2007CB407304), Chinese Academy of Science (KZCX3-SW-431) and National Natural Science Foundation of China (40471129).

\section{References}

Alexander, M., 2000. Aging, bioavailability, and overestimation of risk from environmental pollutants. Environmental Science and Technology 34, 4259-4265.

Chen, Y., Wang, C., Wang, Z., Huang, S., 2004. Assessment of the contamination and genotoxicity of the soil irrigated with wastewater. Plant and Soil 261, 189-196.

Chen, Y., Wang, C., Wang, Z., 2005. Residues and source identification of persistent organic pollutants in farmland soils irrigated by effluents from biological treatment plants. Environmental International 31, 778-783.

Ching, E.W.K., Siu, W.H.L., Lam, P.K.S., Xu, L., Zhang, Y., Richardson, B.J., Wu, R.S.S., 2001. DNA adduct formation and DNA strand breaks in greenlipped mussels (Perna viridis) exposed to benzo[a]pyrene: dose- and timedependent relationships. Marine Pollution Bulletin 42, 603-610. 
De Boeck, M., Toui, N., De Visscher, G., Vande, P.A., Kirsch-Volders, M., 2000. Validation and implementation of an internal standard in comet assay analysis. Mutation Research 469, 181-197.

Donnelly, K.C., Lingenfelter, R., Cizmas, L., Falahatpisheh, M.H., Qian, Y., Tang, Y., Garcia, S., Ramos, K., Tiffany-Castiglioni, E., Mumtaz, M.M., 2004. Toxicity assessment of complex mixtures remains a goal. Environmental Toxicology and Pharmacology 18, 135-141.

Escher, B.I., Hermens, J.M.M., 2002. Modes of action in ecotoxicology: their role in body burdens, species sensitivity, QSARs and mixture effects. Environmental Science and Technology 36, 4201-4217.

Eyambe, G.S., Goven, A.J., Fitzpatrick, L.C., Venables, B.J., Cooper, E.L., 1991. A non-invasive technique for sequential collection of earthworm (Lumbricus terrestris) leukocytes during subchronic immunotoxicity studies. Laboratory Animals 1991 (25), 61-67.

Farmer, P.B., Singh, R., Kaur, B., Sram, R.J., Binkova, B., Kalina, I., Popov, T.A., Garte, S., Taioli, E., Gabelova, A., CebulskaWasilewska, A., 2003. Molecular epidemiology studies of carcinogenic environmental pollutants. Effects of polycyclic aromatic hydrocarbons (PAHs) in environmental pollution on exogenous and oxidative DNA damage. Mutation Research 544, 397-402.

Faust, F., Kassie, F., Knasmüller, S., Boedecker, R.H., Mann, M., MerschSundermann, V., 2004. The use of the alkaline comet assay with lymphocytes in human biomonitoring studies. Mutation Research 566, 209-229.

Husgafvel-Pursiainen, K., 2004. Genotoxicity of environmental tobacco smoke: a review. Mutation Research 567, 427-445.

ISO, 1993. No. 11268-1. Soil Quality on Effects of Pollutants on Earthworms (Eisenia fetida)-Part I: Determination of Acute Toxicity Using Artificial Soil Substrate. International Standard Organization, Geneva, Switzerland.

Lanno, R., Wells, J., Conder, J., Bradham, K., Bastae, N., 2004. The bioavailability of chemicals in soil for earthworms. Ecotoxicology and Environmental Safety 57, 39-47.

Larsen, J.C., Larsen, P.B., 1998. Chemical carcinogens. In: Hester, R.E., Harrison, R.M. (Eds.), Air Pollution and Health. The Royal Society of Chemistry, Cambridge, UK, pp. 33-56.

Livingstone, D.R., 1991. Organic xenobiotic metabolism in marine invertebrates. In: Gilles, R. (Ed.), Advances in Comparative and Environmental Physiology. Springer-Verlag, Berlin, Germany 7, pp. 46-185.

Lutz, W.K., 1998. Dose-response relationships in chemical carcinogenesis: superposition of different mechanisms of action, resulting in linear-nonlinear curves, practical thresholds, J-shapes. Mutation Research 405, $117-124$
Mitchelmore, C.L., Chipman, J.K., 1998. DNA strand breakage in aquatic organisms and the potential value of the comet assay in environmental monitoring. Mutation Research 399, 135-147.

Nesnow, S., Ross, J.A., Mass, M.J., Stoner, G.D., 1998. Studies of mixtures of tumorigenic environmental polycyclic aromatic hydrocarbons in mouse lung: quantitation of interactions. Pathophysiology 5, 110-111(1).

Nisbet, I.C., LaGoy, P.K., 1992. Toxic equivalency factors (TEFs) for polycyclic aromatic hydrocarbons (PAHs). Regulatory Toxicology and Pharmacology 16, 290-300.

OECD, 1984. Earthworm, Acute Toxicity Tests, OECD Guideline for Testing of Chemicals No. 207. Organization for Economic Cooperation and Development, Paris.

Pandrangi, R., Petras, M., Ralph, S., Vrzoc, M., 1995. Alkaline single cell gel (comet) assay and genotoxicity monitoring using bullheads and carp. Environmental and Molecular Mutagenesis 26, 345-356.

Peters, C.A., Knightes, C.D., Brown, D.G., 1999. Long-term composition dynamics of PAH-containing NAPLs and implications for risk assessment. Environmental Science and Technology 33, 4499-4507.

Pfuhler, S., Wolf, H.U., 1996. Detection of DNA-crosslinking agents with the alkaline comet assay. Environmental and Molecular Mutagenesis 27, 196-201.

Roos, P.H., Tschirbs, S., Pfeifer, F., Welge, P., Hack, A., Wilhelm, M., Bolt, H.M., 2004. Risk potentials for humans of original and remediated PAH-contaminated soils: application of biomarkers of effect. Toxicology 205, 181-194.

Saint-Denis, M., Narbonne, J.F., Arnaud, C., Thybaud, E., Riberaa, D., 1999. Biochemical responses of the earthworm Eisenia fetida andrei exposed to contaminated artificial soil: effects of benzo(a)pyrene. Soil Biology and Biochemistry 31, 1837-1846.

Sayles, G.D., Acheson, C.M., Kupferle, M.J., Shan, Y.G., Zhou, Q., Meier, J.R., Chang, L., Brenner, R.C., 1999. Land treatment of PAH-contaminated soil: performance measured by chemical and toxicity assays. Environmental Science and Technology 33, 4310-4317.

Singh, N.P., McCoy, M.T., Tice, R.R., Schneider, E.L., 1988. A simple technique for the quantitation of low levels of DNA damage in individual cells. Experimental Cell Research 175, 184-191.

White, P.A., Claxton, L.D., 2004. Mutagens in contaminated soil: a review. Mutation Research 567, 227-345.

Zang, Y., Zhong, Y., Luo, Y., Kong, Z.M., 2000. Genotoxicity of two novel pesticides for the earthworm, Eisenia fetida. Environmental Pollution $108,271-278$. 